$1-1-2020$

\title{
Balochistan, Self-Determination, and U.S. Foreign Policy
}

Chad G. Marzen

Follow this and additional works at: https://scholarship.law.unc.edu/ncilj

Part of the Law Commons

\section{Recommended Citation}

Chad G. Marzen, Balochistan, Self-Determination, and U.S. Foreign Policy, 45 N.C. J. INT'L L. 195 (2020).

Available at: https://scholarship.law.unc.edu/ncilj/vol45/iss1/4

This Article is brought to you for free and open access by Carolina Law Scholarship Repository. It has been accepted for inclusion in North Carolina Journal of International Law by an authorized editor of Carolina Law Scholarship Repository. For more information, please contact law_repository@unc.edu. 


\section{Balochistan, Self-Determination, and U.S. Foreign Policy}

Chad G. Marzen ${ }^{\dagger 1}$

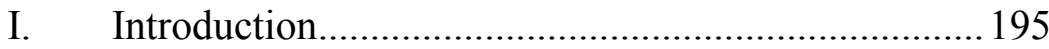

II. Self-Determination in International Law .................. 201

III. Balochistan ............................................................ 204

A. A Brief History of Balochistan ......................... 204

B. Relationship between Balochistan and Pakistan. 205

C. Human Rights Concerns in Balochistan .............207

IV. The Movement Toward Self-Determination for

Balochistan ........................................................209

A. Baloch Nationalist Movement ........................... 209

B. The Efforts of Peter Tatchell .............................210

C. The United States Congress and H. Con. Res.

104

D. U.S. Foreign Policy and Balochistan .................216

E. International Law, Self-Determination and

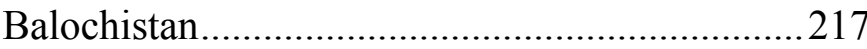

1. Self-Determination as a Remedial Right Due to Human Rights Violations ..............................218

2. Self-Determination as a "Last Resort" Due to Lack of Meaningful Access to Government..220

F. An Opportunity for Conservative and Progressive Bipartisan Support for Self-Determination for Balochistan? ...................................................... 222

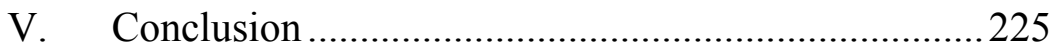

\section{Introduction}

In the past several decades, the principle of self-determination

$\uparrow$ Chad G. Marzen is an Associate Professor of Legal Studies in Business at Florida State University, College of Business - Department of Risk Management/Insurance, Real Estate, and Legal Studies. The author can be reached at cmarzen@fsu.edu.

1 The author would like to thank Kyle Gliwa, an MBA student at Florida State University, for his assistance in compiling copies of sources for this article, as well as the entire staff of the North Carolina Journal of International Law. Thank you. 
has evolved and developed into a cardinal principle of international law. ${ }^{2}$ Recognized today generally as a jus cogens (peremptory) norm of international law, ${ }^{3}$ self-determination is generally viewed as including the right of "peoples" to express their identity as a sovereign nation. ${ }^{4}$ Article 1(2) of the United Nations Charter elevates the principle of self-determination in international law, as one of the purposes of the United Nations is "to develop friendly relations among nations based on respect for the principle of equal rights and self-determination of peoples." ${ }_{5}$ There are generally two different types of self-determination: external and internal. External self-determination has been explained by the United Nations General Assembly as the right of all peoples "freely to determine, without external interference, their political status and to pursue their economic, social and cultural development."6 Internal selfdetermination has been defined by the Supreme Court of Canada in Reference re Secession of Quebec ("Quebec Case") as "a people's pursuit of its political, economic, social and cultural development within the framework of an existing state."7

The contours of the principle of self-determination in international law have garnered much academic commentary. ${ }^{8} \mathrm{~A}$

2 See Lori Fisler Damrosch, louis Henkin, Sean D. Murphy \& Hans Smit, INTERNATIONAL LAW: CASES AND MATERIALS 324 (5th ed. 2009).

3 See Christian Leathley, Gibraltar's Quest for Self-Determination: A Critique of Gibraltar's New Constitution, 9 OR. REV. INT'L L. 153, 177 (2007) (“As a norm of jus cogens the right to self-determination has a status higher than any other in international law. It is a norm accepted and recognised by the international community of States as a whole, from which no derogation is permitted and which can only be modified by a subsequent norm of general international law having the same character.").

4 Id. at 170.

5 U.N. Charter art. 1, II 2.

6 G.A. Res. 2625 (XXV), Declaration on Principles of International Law concerning Friendly Relations and Co-operation among States in accordance with the Charter of the United Nations, at 123 (Oct. 24, 1970) [hereinafter United Nations G.A. Res 2625].

7 Reference re Secession of Quebec, [1998] 37 I.L.M. 1340, 1371.

8 See, e.g., Milena Sterio, Self-Determination and Secession Under International Law: The New Framework, 21 ILSA J. INT'L \& COMP. L. 293 (2015) (observing that most cases of external self-determination in the modern era occur outside of the context of decolonization or foreign occupation and arguing a new international law framework should be developed to apply to cases of modern-day secession in international law); Dr. Glen Anderson, Unilateral Non-Colonial Secession and the Criteria for Statehood in International Law, 41 BROOK. J. INT'L L. 1 (2015) (analyzing international legal principles in cases where secessionist groups use force to attempt to achieve self-determination); John R. Ablan, Note, Signal and Affirm: How the United Nations Should Articulate the 
number of groups throughout the world have asserted claims of external self-determination. For example, there have been movements for self-determination in South Sudan, ${ }^{9}$ East Timor, ${ }^{10}$

Right to Remedial Secession, 45 VAND. J. TRANSNAT'L L. 211 (2012) (advocating that secession in international law be recognized in cases where a resolution of the General Assembly recognizes the right in a particular case and the International Court of Justice has affirmed); Thomas W. Simon, Remedial Secession: What the Law Should Have Done, From Katanga to Kosovo, 40 GA. J. INT'L \& CoMP. L. 105 (2011) (endorsing a remedial model of secession, which would recognize secession under international law generally in cases where methods of internal self-determination have failed); Hurst Hannum, Rethinking Self-Determination, 34 VA. J. INT'L L. 1 (1993).

9 See, e.g., Jure Vidmar, South Sudan and the International Legal Framework Governing the Emergence and Delimitation of New States, 47 TEX. INT'L L.J. 541 (2012); Christopher Zambakari, Post-Referendum Sudan: The Nation-Building Project and its Challenges, 9 Rutgers J.L. \& PuB. Pol'y 505 (2012); Salman M.A. Salman, South Sudan Road to Independence: Broken Promises and Lost Opportunities, 26 PAC. MCGEORGE Global Bus. \& Dev. L.J. 343 (2013); Christopher Zambakari, Post-Referendum South Sudan: Political Violence, New Sudan, and Democratic Nation-Building, 18 GEO. Pub. POL'y REV. 41 (2013).

10 See, e.g., Stephanie A. Paulk, Comment, Determination of Self in a Decolonized Territory: The Dutch, the Indonesians, and the East Timorese, 15 EMORY INT'L L. REV. 267 (2001); Jonathan I. Charney, Self-Determination: Chechnya, Kosovo, and East Timor, 34 Vand. J. Transnat'L L. 455 (2001); Roger S. Clark, Symposium, Recent Developments in East Timor: East Timor, Indonesia, and the International Community, 14 TEMP. InT'L \& Comp. L.J. 75 (2000); Henry J. Richardson, A Critical Thought on Self Determination for East Timor and Kosovo, 14 TEMP. INT'L \& CoMP. L.J. 101 (2000); Thomas D. Grant, East Timor, the U.N. System, and Enforcing Non-Recognition in International Law, 33 VAND. J. TRANSNAT'L L. 273 (2000). 
Western Sahara, ${ }^{11}$ Quebec, ${ }^{12}$ Kashmir, ${ }^{13}$ Kurdistan, ${ }^{14}$ Chechnya, ${ }^{15}$

11 See, e.g., Armin Steinbach, The Western Sahara Dispute: A Case for the ECJ?, 18 Colum. J. EuR. L. 415 (2012); Laurence S. Hanauer, The Irrelevance of SelfDetermination Law to Ethno-National Conflict: A New Look at the Western Sahara Case, 9 EMORY INT'L L. REV. 133 (1995).

12 See, e.g., Stephen Alvstad, The Quebec Secession Issue, with an Emphasis on the “Cultural" Side of the Equation, 18 TEMP. INT'L \& COMP. L.J. 89 (2004); Johan D. Van Der Vyver, Self-Determination of the Peoples of Quebec Under International Law, $10 \mathrm{~J}$. Transnat'L L. \& Pol'y 1 (2000); L. Kinvin Wroth, Quebec, Canada and the First Nations: The Problem of Secession, 23 VT. L. REV. 709 (1999); Jean-Francois GaudreaultDesBiens, The Quebec Secession Reference and the Judicial Arbitration of Conflicting Narratives About Law, Democracy, and Identity, 23 VT. L. REV. 793 (1999); Roya M. Hanna, Comment, Right to Self-Determination in In Re Secession of Quebec, 23 MD. J. INT'L L. \& TRADE 213 (1999); Kevin MacMillan, Comment, Secession Perspectives and the Independence of Quebec, 7 TuL. J. INT'L \& COMP. L. 333 (1999); Gregory Marchildon \& Edward Maxwell, Quebec's Right to Secession under Canadian and International Law, 32 VA. J. INT'L L. 583 (1992).

13 See, e.g., Sikander Shah, An In-Depth Analysis of the Evolution of SelfDetermination under International Law and the Ensuing Impact on the Kashmiri Freedom Struggle, Past and Present, 34 N. KY. L. REV. 29 (2007); Brian Farrell, The Role of International Law in the Kashmir Conflict, 21 PenN. St. InT'L L. Rev. 293 (2003).

14 See, e.g., Thomas D. Grant, Kurdistan After the Referendum of September 25, 2017: Statehood, Recognition, and International Law, 46 GA. J. INT'L \& CoMP. L. 369 (2018); Craig Douglas Albert, Dignity Takings and Dignity Restoration No Place to Call Home: The Iraqi Kurds Under the Ba'ath, Saddam Hussein, and ISIS, 92 CHI.-KENT L. REV. 817 (2017); Matthew Packard, Note \& Comment, Earning Independence in Iraqi Kurdistan, 27 TemP. InT'L \& ComP. L. J. 177 (2013); Michael J. Kelly, The Kurdish Regional Constitution within the Framework of the Iraqi Federal Constitution: A Struggle for Sovereignty, Oil, Ethnic Identity, and the Prospects for a Reverse Supremacy Clause, 114 PA. St. L. Rev. 707 (2010); Philip S. Hadji, Note, The Case for Kurdish Statehood in Iraq, 41 CASE W. Res. J. InT'L L. 513 (2009); Gregory J. Ewald, The Kurds' Right to Secede Under International Law: Self-Determination Prevails Over Political Manipulation, 22 DENV. J. INT'L L. \& POL'Y 375 (1994).

15 See, e.g., Nicola Bunick, Note, Chechnya: Access Denied, 40 GEO. J. INT'L L. 985 (2009); Cherylyn Brandt Ahrens, Note, Chechnya and the Right of Self-Determination, 42 Colum. J. TRansnat'L L. 575 (2004); Thomas D. Grant, A Panel of Experts for Chechnya: Purposes and Prospects in Light of International Law, 40 VA. J. INT'L L. 115 (1999). 
Kosovo, ${ }^{16}$ Gibraltar, ${ }^{17}$ Catalonia, ${ }^{18}$ Crimea, ${ }^{19}$ and Somaliland ${ }^{20}$ in recent years. Some of these movements, such as the movements in

16 See, e.g., Christopher R. Rossi, Impaled on Morton's Fork: Kosovo, Crimea, and the Sui Generis Circumstance, 30 EMORY INT'L L. REV. 353 (2016); Timothy William Waters, Misplaced Boldness: The Avoidance of Substance in the International Court of Justice's Kosovo Opinion, 23 DuKE J. COMP. \& INT'L L. 267 (2013); Samuel Ethan Meller, Note, The Kosovo Case: An Argument for a Remedial Declaration of Independence, 40 GA. J. InT'L \& Comp. L. 833 (2012); Milena Sterio, The Kosovar Declaration of Independence: "Botching the Balkans" or Respecting International Law?, 37 GA. J. INT'L \& Comp. L. 267 (2009); Christopher J. Borgen, Symposium, Great Power Politics: The Language of Law and the Practice of Politics: Great Powers and the Rhetoric of SelfDetermination in the Cases of Kosovo and South Ossetia, 10 CHI. J. INT'L L. 1 (2009); Ronald Thomas, Note, Transitional Justice: War Crimes Tribunals and Establishing the Rule of Law in Post-Conflict Countries: The Distinct Cases of Kosovo and South Ossetia: Deciding the Questions of Independence on the Merits and International Law, 32 FordHAM INT'L L. J. 1990 (2009); Jure Vidmar, International Legal Responses to Kosovo's Declaration of Independence, 42 VAND. J. TRANSNAT'L L. 779 (2009); K. William Watson, Comment, When in the Course of Human Events: Kosovo's Independence and the Law of Secession, 17 TuL. J. InT'L \& CoMP. L. 267 (2008); Daniel Fierstein, Note, Kosovo's Declaration of Independence: An Incident Analysis of Legality, Policy and Future Implications, 26 B.U. INT'L L. J. 417 (2008).

17 See, e.g., Inge V. Porter, Two Case Studies in Self-Determination: The Rock and the Bailiwick, 4 SAN DiEGo InT'L L. J. 339 (2003).

18 See, e.g., Carmen Gonzalez, Note, The Catalan National Identity and Catalonia's Bid for Independence, 32 ConN. J. InT'L L. 115 (2016); Christopher K. Connolly, Independence in Europe: Secession, Sovereignty, and the European Union, 24 DUKE J. Comp. \& InT'L L. 51 (2013); Dr. Pau Puig i Scotoni, Symposium, Exercising SelfDetermination Without Jeopardising the Rights of the Others: The Catalan Model, 14 ST. Thomas L. ReV. 395 (2001).

19 See, e.g., Thomas W. White, Jr., Referendum in Crimea: Developing International Law on "Territorial Realignment" Referendums, 38 Hous. J. INT'L L. 843 (2016); Alisa Gdalina, Note, Crimea and the Right to Self-Determination: Questioning the Legality of Crimea's Secession from Ukraine, 24 CARDOZO J. INT'L \& CoMP. L. 531 (2016); Stefan Kirchner, Crimea's Declaration of Independence and the Subsequent Annexation by Russia Under International Law, 18 GonZ. J. INT'L L. 1 (2015); R.J. Delahunty, The Crimean Crisis, 9 U. St. Thomas J. L. \& Pub. Pol'y 125 (2014).

20 See, e.g., Dimitrios Lalos, Note, Between Statehood and Somalia: Reflections of Somaliland Statehood, 10 Wash. U. Global Stud. L. ReV. 789 (2011); Aaron Kreuter, Note, Self-Determination, Sovereignty, and the Failure of States: Somaliland and the Case for Justified Secession, 19 MinN. J. INT'L L. 363 (2010); Benjamin R. Farley, Comment, Calling a State a State: Somaliland and International Recognition, 24 EMORY INT'L L. REv. 777 (2010); Brad Poore, Somaliland: Shackled to a Failed State, 45 STAN. J. InT'L L. 117 (2009); Alison K. Eggers, Note, When is a State a State? The Case for Recognition of Somaliland, 30 B.C. INT'L \& COMP. L. REV. 211 (2007). 
South Sudan, ${ }^{21}$ Timor-Leste, ${ }^{22}$ and Montenegro, ${ }^{23}$ have resulted in the formation of sovereign nations which have received recognition as member states of the United Nations. ${ }^{24}$

In recent years, a more visible movement for self-determination in Balochistan has emerged. Balochistan, Pakistan's largest province in terms of geographic size, ${ }^{25}$ is rich in natural resources such as gold, copper, coal, chromite, and natural gas. ${ }^{26}$ Between 1948 and 1977, four different conflicts for Baloch independence were fought. ${ }^{27}$ Since the mid-2000s, an intermittent conflict between Baloch separatist groups and Pakistan has remained prevalent in Balochistan. ${ }^{28}$ Reportedly, a growing list of human rights abuses have occurred in Balochistan, including the killings of teachers, journalists, and activists, as well as kidnappings and forced disappearances. ${ }^{29}$

This Article examines the question of self-determination for

21 See Jeffrey Gettleman, After Years of Struggle, South Sudan Becomes a New $\begin{array}{lllll}\text { Nation, } & \text { N.Y. } & \text { TiMES } & \text { (July }\end{array}$ https://www.nytimes.com/2011/07/10/world/africa/10sudan.html [https://perma.cc/Q84C-6GE6].

22 See East Timor wins independence, ThE GuARdian (Sept. 6, 2001), https://www.theguardian.com/world/2001/sep/06/indonesia.easttimor [https://perma.cc/4GBF-K2FQ].

23 See Predrag Milic, Montenegro Declares Its Independence From Serbia, WASH. Post (June 4, 2006), http://www.washingtonpost.com/wpdyn/content/article/2006/06/03/AR2006060300899.html_[https://perma.cc/57R8-FA5U].

24 See Member States, United NATIONS (Sept. 15, 2019, 3:24 PM), https://www.un.org/en/member-states/ [https://perma.cc/6LP6-2RLJ].

25 See Qasim Nauman, What is Pakistan's Balochistan Insurgency and Why is India's Modi Talking About It?, WALL ST. J. (Aug. 17, 2016, 6:38 AM), https://blogs.wsj.com/briefly/2016/08/17/what-is-pakistans-balochistan-insurgency-andwhy-is-indias-modi-talking-about-it-the-short-answer/ [https://perma.cc/Z3KE-Z2D9].

26 See Imdad Baloch, Balochistan: Rich in Natural Resources and Poor in Living Conditions, THE BALOCHISTAN POINT (Feb. 23, 2015), http://thebalochistanpoint.com/balochistan-rich-in-natural-resources-and-poor-in-livingconditions/ [https://perma.cc/3HST-9RZL].

27 See Balochistan Insurgency, GlobalSecurity.org (Sept. 7, 2018), https://www.globalsecurity.org/military/world/war/pakistan1.htm [https://perma.cc/6Y4K-NLW7].

28 See Nauman, supra note 25.

29 See Husain Haqqani, Injustices in Balochistan Need the World's Attention, THE WIRE (Sept. 24, 2017), https://thewire.in/external-affairs/balochistans-injustices-needworlds-attention [https://perma.cc/R4QH-MMZN]. 
Balochistan. ${ }^{30}$ Part I briefly mentions several significant sources of international law that have enshrined self-determination as a fundamental principle of international law. Part II discusses the history of Balochistan, its relationship with Pakistan, and human rights concerns in the region. Part III analyzes the movement for self-determination in Balochistan and considers the possibility of a progressive and conservative coalition to work together toward selfdetermination for Balochistan. Finally, the Article concludes that the current situation in Balochistan offers an opportunity for both progressives and conservatives within the United States to work together to discuss the possibility of self-determination for Balochistan.

\section{Self-Determination in International Law}

Self-determination in international law was first embraced as a "principle" of international law $^{31}$ in Article 1(2) of the United Nations Charter, which recognizes the "self-determination of peoples." 32 Subsequent key international documents have enshrined this principle. The United Nations General Assembly also strongly endorsed self-determination in a 1970 resolution where it stated that the "principle of equal rights and self-determination of peoples constitutes a significant contribution to contemporary international law, and that its effective application is of paramount importance for the promotion of friendly relations among States, based on respect for the principle of sovereign equality." 33 This resolution additionally requires states to refrain from any "forcible action" which interferes with the right of self-determination and also provides that "subjection of peoples to alien subjugation, domination and exploitation constitutes a violation" of the principle of self-determination. ${ }^{34}$

Other international instruments have similarly affirmed the right to self-determination. Article 1(1) of the International Covenant on

30 See Maryam S. Khan, Ethnic Federalism in Pakistan: Federal Design, Construction of Ethno-Linguistic Identity \& Group Conflict, 30 HARV. J. RACIAL \& ETHNIC Just. 77 (2014); Tayyab Mahmud, Colonial Cartographies, Postcolonial Borders, and Enduring Failures of International Law: The Unending Wars Along the AfghanistanPakistan Frontier, 36 Brook. J. INT'L L. 1 (2010).

31 DAmRosch, supra note 2, at 324.

32 U.N. Charter art. 1, II 2.

33 United Nations G.A. Res 2625, supra note 6, at 122.

34 Id. at $122-23$. 
Economic, Social and Cultural Rights provides that all peoples have the right to "freely determine their political status," as well as to "freely pursue their economic, social and cultural development." 35

As international law has developed, the right of selfdetermination has become fully recognized in two types of cases: the first type of case is where a colonial peoples seeks the right to self-determination, and the other is in cases of foreign occupation or subjugation. ${ }^{36}$ The case of secession, which encompasses the aims of most self-determination movements today, is unsettled in international law. ${ }^{37}$

Both the Supreme Court of Canada and the International Court of Justice ("ICJ") have examined the question of secession under international legal principles. In 1998, the Supreme Court of Canada addressed the question of whether the government of Quebec could secede from Canada unilaterally under principles of international law in the Quebec Case. ${ }^{38}$ While the Supreme Court of Canada answered the question in the negative, ${ }^{39}$ it addressed the definition of "peoples" for purposes of self-determination ${ }^{40}$ and mentioned another instance where secession would be permissible under international law. ${ }^{41}$ The Supreme Court of Canada noted that, while the precise definition of "people" is uncertain, ${ }^{42}$ the sharing of a common language and culture would be characteristics considered in determining whether a group was a "people." 43 Finally, the Supreme Court of Canada also remarked that in cases where a people is denied their right to internal self-determination, the people is entitled to secession as a "last resort." 44 In essence, this would take place in cases where a people "is denied meaningful access to

35 International Covenant on Economic, Social and Cultural Rights, Dec. 16, 1966, 6 I.L.M. 360 (1967), 993 U.N.T.S. 3, art. 1(1). See also International Covenant on Civil and Political Rights, Dec. 16, 1966, 6 I.L.M. 368 (1967), 999 U.N.T.S. 171, art. 1(1) (endorsing the right of self-determination).

36 See Valerie Epps, Secession, Stagnation and the State-Centered Version of International Law, 21 ILSA J. INT'L \& COMP. L. 307, 309-11 (2015).

37 Id. at 309-13.

38 See Reference re Secession of Quebec, 37 I.L.M. at 1342.

39 Id. at 1376.

40 Id. at $1370-71$.

41 Id. at 1373.

42 Id. at 1370.

43 Id. at 1371.

44 See Reference re Secession of Quebec, 37 I.L.M. at 1372-73. 
government to pursue their political, economic, social and cultural development." 45

On February 17, 2008, Kosovo unilaterally declared its independence from Serbia. ${ }^{46}$ In 2010, in an advisory opinion, the ICJ decided that Kosovo's unilateral declaration of independence from Serbia did not violate international law because "general international law contains no applicable prohibition of declarations of independence." 47 However, the ICJ did not address the question of whether international law afforded Kosovo a positive right to declare independence. ${ }^{48}$ Thus, the ICJ avoided further addressing the larger question in international law as to when a people may have a general right to declare independence. ${ }^{49}$ Two commentators, Roland Tricot and Barrie Sander, have observed that the message of the ICJ in the Kosovo Advisory Opinion was that disputes over declarations of independence "should be left to the international community to decide through political fora." ${ }_{50}$

While the precise limitations of self-determination are unsettled in international law, it is clear that another fundamental principle of international law is respect for the territorial integrity of a state. ${ }^{51}$ The principle of territorial integrity appears prominently in Article 2(4) of the United Nations Charter, as the Charter calls for all member states to "refrain in their international relations from the

45 Id. at 1373.

46 See Dan Bilefsky, Kosovo Declares its Independence from Serbia, N.Y. TIMES (Feb. 18, 2008), https://www.nytimes.com/2008/02/18/world/europe/18kosovo.html [https://perma.cc/8FKQ-DFRD].

47 Accordance with International Law of the Unilateral Declaration of Independence in Respect of Kosovo, Advisory Opinion, 2010 I.C.J. 403, II 84 (July 22) [hereinafter Kosovo Advisory Opinion].

48 Id. II 56.

49 See generally Richard Falk, Agora: The ICJ's Kosovo Advisory Opinion: The Kosovo Advisory Opinion: Conflict Resolution and Precedent, 105 AM. J. INT'L L. 50 (2011) (arguing the "[c]ourt behaved in a somewhat political manner, deferring to geopolitical wishes by rather unexpectedly validating the Kosovo declaration, yet seeking to prevent wider policy effects, which seemed to avoid a simple textual application of the intentions of the Security Council as set forth in Resolution 1244").

50 Roland Tricot \& Barrie Sander, Recent Developments: The Broader Consequences of the International Court of Justice's Advisory Opinion on the Unilateral Declaration of Independence in Respect of Kosovo, 49 Colum. J. TRANSNAT'L L. 321, 362 (2011).

51 See Paul C. Szasz, The Irresistible Force of Self-Determination Meets the Impregnable Fortress of Territorial Integrity: A Cautionary Fairy Tale about Clashes in Kosovo and Elsewhere, 28 GA. J. INT'L \& COMP. L. 1, 2 (1999). 
threat or use of force against the territorial integrity or political independence of any state[.]" 52 Both the principle of selfdetermination and respect for the territorial integrity of states must be balanced in international law. ${ }^{53}$ The case of self-determination for Balochistan is one such issue that must be balanced between both principles.

\section{Balochistan}

\section{A. A Brief History of Balochistan}

Today, Balochistan is Pakistan's largest geographical province. ${ }^{54}$ Two academic commentators have noted that the Baloch have historically been comprised of a number of ethnic groups, including peoples of African origin, Arabs, Persians, Turks, Kurds, Dravidians, and Sewais (Hindu). ${ }^{55}$ Culturally, the Baloch people are generally regarded as more secular and moderate. ${ }^{56}$ The majority of the population speaks Balochi, although a significant number of individuals in Balochistan speak Pashto. ${ }^{57}$ The population of Balochistan is primarily rural ${ }^{58}$ and approximately two-thirds of the 12 million people ${ }^{59}$ live outside of urban areas. ${ }^{60}$

From 1839 to 1947 , Kalat was a semi-autonomous state. ${ }^{61}$

52 U.N. Charter art. 2, II 4.

53 See generally Szasz, supra note 51 (citing the Decolonization Resolution of the UN General Assembly proclaimed that all people "have the right to self-determination ... [and] any attempt aimed of the disruption of the national unity and the territorial integrity of a country is incompatible with the purposes and principles of the Charter of the United Nations" (brackets and internal quotation marks omitted)).

54 Malik Siraj Akbar, In Balochistan, Dying Hopes for Peace, N.Y. TimEs (July 19, 2018), https://www.nytimes.com/2018/07/19/opinion/pakistan-elections-balochistanislamic-state.html [https://perma.cc/D8D3-3J9T].

55 Manzoor Ahmed \& Gulawar Khan, The History of Baloch and Balochistan: A Critical Appraisal, 32 S. AsIAN STUd. 1, 4 (2017).

56 Baluchistan: Hearing Before the Subcomm. of Oversight and Investigations of the Com. on Foreign Affairs, 112th Cong. 7 (2012) [hereinafter Baluchistan Hearings] (statement of U.S. Rep. Brad Sherman of Cal.).

57 Id. at 71 (statement of Ali Dayan Hasan, Pakistan Director, Human Rights Watch).

58 Id.

59 Haqqani, supra note 29.

60 Baluchistan Hearings, supra note 56, at 71 (statement of Ali Dayan Hasan, Pakistan Director, Human Rights Watch).

61 Id. See also Brian Spooner, The British period, 1839-1947, BALOCHI LinguIST (Apr. 7, 2011), https://balochilinguist.wordpress.com/2011/04/07/the-british-period1839-1947/ [https://perma.cc/X7DT-ER2Z] ("From 1839 to 1947 the greater part of 
While Mir Chakar Khan Rind, a Baloch chieftain, formed a confederacy of Baloch tribes in the 1480s, the founding of the Baloch nation is generally viewed as emerging with Mir Ahmed Khan's formation of the Kalat Confederacy in the 1660s. ${ }^{62}$ The Khan of Kalat thus had authority over Balochistan until the arrival of the British in $1839 .{ }^{63}$ In 1947, the vast majority of tribal chiefs in Balochistan yielded their territory "to the new state of Pakistan." ${ }^{64}$ That same year, the Khan of Kalat declared independence. ${ }^{65}$ However, the Pakistani military crushed the insurgency after approximately eight months. ${ }^{66}$ Thus, Balochistan was partitioned and eventually Balochistan officially became a province of Pakistan in 1970. ${ }^{67}$ Since 1947, five distinct conflicts for independence have erupted in Balochistan: conflicts have occurred in 1948, from 1958 to 1959 , from 1963 to 1969 , from 1973 to 1977 , and from 2004 to the present. ${ }^{68}$ The conflict between 1973 and 1977 was a particularly brutal one, where some areas of Balochistan were bombed at random. ${ }^{69}$ By estimates, over 6,000 Baloch and 3,300 Pakistani soldiers were killed in this conflict. ${ }^{70}$ Since 2004, a civil war has gripped Balochistan. ${ }^{71}$

\section{B. Relationship between Balochistan and Pakistan}

Balochistan is regarded as the most impoverished province in Pakistan. ${ }^{72}$ According to a 2016 report on multidimensional poverty

Baluchistan was - formally or informally - under the British Empire, whose interest was essentially in securing and protecting its North-West Frontier Province from both Afghanistan and Iran. At a particular stage in this endeavor the British negotiated formal international borders through the territories of Baluch tribes with both Iran and Afghanistan, roughly according to the effective sphere of influence of the khan of Kalat, but with some attention to the interests of local leaders.").

62 Ahmed \& Khan, supra note 55, at 5.

63 Id. at 7.

64 See Mary Anne Weaver, Pakistan: Deep Inside The World's Most Frightening StATE 94 (Farrar, Straus and Giroux rev. ed. 2010).

$65 I d$.

66 Id.

67 Ahmed \& Khan, supra note 55, at 7.

68 Balochistan Insurgency, supra note 27.

69 WEAVER, supra note 64, at 95.

70 Id.

71 See Balochistan Insurgency, supra note 27.

72 Baluchistan Hearings, supra note 56, at 4 (opening statement of U.S. Rep. Dana 
in Pakistan, approximately 71 percent of the population of Balochistan were living in multidimensional poverty. ${ }^{73}$ The current literacy rate in Balochistan is 41 percent. $^{74}$

Despite widespread poverty in Balochistan, Balochistan contains an abundance of natural resources such as gold, coal, copper, and uranium, ${ }^{75}$ as well as a large supply of natural gas. ${ }^{76}$ However, a significant number of districts in the Balochistan province lack access to natural gas. ${ }^{77}$

In recent years, Balochistan's major port, Gwadar, has been developed with substantial Chinese investment to become a major center of trade along the Strait of Hormuz. ${ }^{78}$ The China-Pakistan Economic Corridor ("CPEC"), an approximately $\$ 62$ billion alliance between Pakistan and China, has greatly increased China's influence in Balochistan. ${ }^{79}$

Pakistan has aggressively opposed and suppressed efforts for Baloch self-determination. Additionally, Pakistan has allegedly supported targeted assassinations and kidnappings in the current conflict. ${ }^{80}$ During the ongoing conflict with Baloch nationalists,

Rohrabacher of Cal.).

73 See Adnan Aamir, 71 Percent People in Balochistan Live Below Poverty Line: Report, BALOCHISTAN VoICES, 1 (June 20, 2016), http://balochistanvoices.com/2016/06/71-percent-people-balochistan-live-poverty-linereport/ [https://perma.cc/4VUP-5H3N].

74 See Fajar Nadeem, Illiteracy in Balochistan, Voice of BALOChistan (Feb. 28, 2018), https://voiceofbalochistan.pk/opinions-and-articles/social-development/illiteracyin-balochistan/ [https://perma.cc/H36E-SBSW].

75 Baluchistan Hearings, supra note 56, at 4 (opening statement of United States Rep. Dana Rohrabacher of Cal.).

76 See Syed Fazl-E-Haider, Oil \& Gas Future in Balochistan: More Exploration Activities Required, PAK. \& GULF Economist (Jan. 22, 2018), http://www.pakistaneconomist.com/2018/01/22/oil-gas-future-balochistan-explorationactivities-required/ [https://perma.cc/Q6Y5-2GGW].

77 See Saleem Shahid, Gas supply demanded in all Districts of Balochistan, DAwN (Aug. 29, 2017), https://www.dawn.com/news/1354660 [https://perma.cc/A6T4-3BKR].

78 Baluchistan Hearings, supra note 56, at 4 (opening statement of U.S. Rep. Dana Rohrabacher of Cal.).

79 See Patrick Wintour, 'All-weather friendship': but is Pakistan Relying too heavily on China?, THE GuARDIAN (Aug. 3, 2018), https://www.theguardian.com/cities/2018/aug/03/all-weather-friendship-but-is-pakistanrelying-too-heavily-on-china [https://perma.cc/G778-687D].

80 See Frederic Grare, Carnegie Endowment for International Peace, Balochistan: The State Versus the Nation 4 (Apr. 2013) ("The Pakistani military has so far proven unable to eliminate militant organizations and the larger nationalist 
Pakistan has gone so far as to reportedly back religious militants who are fighting the Baloch. ${ }^{81}$ This appears to be part of a general strategy, as one commentator notes, of an "Islamization" of the province. ${ }^{82}$ Pakistan has also suppressed Baloch cultural identity for example, the Balochi language is not taught in local schools in Balochistan. ${ }^{83}$ These efforts, and the growing influence of China in Balochistan, are viewed by some as a conscious effort of Pakistan to convert the Baloch into a minority in Balochistan. ${ }^{84}$

\section{Human Rights Concerns in Balochistan}

The violence in Balochistan has also been acknowledged by the United States Department of State, which urges United States citizens to refrain from travel to Balochistan, citing violence resulting from the separatist movement and terrorism. ${ }^{85}$ Professor

movement, despite conducting targeted assassination campaigns and kidnappings.”).

81 See James M. Dorsey, The US-Saudi Plot for Iran that Spells Trouble for China's new Silk Road, South China Morning Post (May 27, 2017, 4:00 PM), https://www.scmp.com/week-asia/geopolitics/article/2095734/us-saudi-plot-iran-spellstrouble-chinas-new-silk-road [https://perma.cc/43UH-VPXB] ("Balochistan has long been troubled by a low level nationalist insurgency. To counter this, Pakistan has backed religious militants.").

82 See GRARE, supra note 80, at 4 ("It was the state's repressive response that radicalized most elements of the 'nationalist' movement.... The Pakistani security establishment ... has been unable to impose its writ on the province, much less propose viable alternative structures. Meanwhile, the security establishment has exacerbated ethnic tensions .... [A]nd allegedly, the security establishment has lost control of its radical proxy groups. The attempted Islamization of the province has led to less, not greater, control for the central government, and a hotbed of extremism is developing in a part of the population where it was previously unknown.").

83 See Dipanjan Roy Chaudhury, Baloch children don't learn Balochi in schools, but set to be taught Chinese, THE ECON. TIMES (Oct. 4, 2018), https://economictimes.indiatimes.com/news/international/world-news/baloch-childrendont-learn-balochi-in-schools-but-set-to-be-taught-chinese/articleshow/66062348.cms [https://perma.cc/YBY7-KJNH] (describing an order to teach Chinese to schoolchildren in Gwadar, even as the Balochi language is not taught).

84 See Hassan Hamdam, Self-Determination and the Baloch National Question, $\begin{array}{llll}\text { BALOCHISTAN TIMES (July 2017), } & \text { 10, }\end{array}$ [https://perma.cc/4QBP-YHAA] (“[T]hese states [Pakistan in particular] are systemically implementing a policy of bringing about demographic changes thus converting the Baloch into a minority in their motherland.").

85 See U.S. Dep't of State, Bureau of Consular Affairs, Pakistan Travel Advisory, Travel.State.Gov (Aug. 1, 2018), https://travel.state.gov/content/travel/en/traveladvisories/traveladvisories/pakistan-traveladvisory.html [https://perma.cc/6TWN-EDGD] ("Active terrorist groups, an active separatist movement, sectarian conflicts, and deadly terrorist attacks against civilians, 
Christine Fair of Georgetown University has testified that the human rights record in Balochistan is "appalling." 86 Acts of terror continue to occur in Balochistan, and political activists, journalists, and teachers are often targets of violence. ${ }^{87}$

Since the beginning of the most recent conflict - since around 2004 - human rights organizations have reported numerous instances of torture, excessive use of force, disappearances, and displacement of civilians. ${ }^{88}$ The United States Department of State reported that nearly 200 civilians were killed due to terrorismrelated violence in 2017. ${ }^{89}$ While the Pakistani security forces have been accused of many human rights violations, militant Baloch nationalist groups have also been accused of human rights violations during the current conflict. ${ }^{90}$ In early July 2019, the United States Department of State placed the Balochistan Liberation Army, ${ }^{91}$ a militant Baloch nationalist group, on its Specially Designated Global Terrorist list. ${ }^{92}$ The Balochistan Liberation Army has reportedly "undermined the hold of the traditional tribal chiefs over the Baloch society" (who have also generally supported Baloch independence) and the organization has been banned in

government offices, and security forces destabilize the province, including all major cities.").

86 Id. at 10 (testimony of statement of Assistant Professor Christine Fair, PhD., Georgetown University).

87 U.S. Dep't of State, Bureau of Democracy, H.R. and Lab., Pakistan 2017 Human Rights Report, COUnTRy REPORTS On Human Rights PRACTICE FOR 20173 (2017).

88 See Baluchistan Hearings, supra note 56, at 74 (statement of Ali Dayan Hasan) ("Pakistani human rights organizations have recorded numerous human rights violations by security forces, including extrajudicial executions, torture, enforced disappearances, forced displacement, and excessive use of force.").

$89 \mathrm{Id}$.

90 Id. at 75 (statement of Ali Dayan Hasan) (“Armed militant groups in Balochistan are responsible for targeted killings and destroying property .... Militant nationalists groups ... have claimed responsibility for most killings of non-Baloch civilians, including teachers and other education personnel.").

91 See generally Kallol Bhattacherjee, Explained: The Baloch Liberation Army, THE HINDU (July 3, 2019), https://www.thehindu.com/news/international/explained-thebaloch-liberation-army/article28273960.ece [https://perma.cc/MY7Y-VWZK] (describing the size, history, leadership, and goals of the Baloch Liberation Army).

92 Geeta Mohan \& Hamza Ameer, US adds Balochistan Liberation Army to terrorism list, INDIA TODAY (July 3, 2019), https://www.indiatoday.in/world/story/us-addsbalochistan-liberation-army-to-terrorism-list-1560794-2019-07-03

[https://perma.cc/4WM5-6MCH]. 
Pakistan since 2006. ${ }^{93}$

Widespread extrajudicial killings are also prevalent in Balochistan. Security forces have targeted political activists and suspected Baloch separatists. ${ }^{94}$ Between 2011 and 2016, approximately 1,000 extrajudicial killings occurred. ${ }^{95}$ These incidents are often "kill and dump" actions, where security forces abduct and kill an individual, and then abandon the body. ${ }^{96}$ The presence of widespread human rights abuses throughout Balochistan, and the potential of Baloch independence to ameliorate them, is one of the arguments commonly cited by proponents of self-determination for Balochistan.

\section{The Movement Toward Self-Determination for Balochistan}

\section{A. Baloch Nationalist Movement}

The origins of Baloch nationalism began with the arrival of the British in Balochistan in 1839. ${ }^{97}$ As Professors Gulawar Khan and Manzoor Ahmed have remarked, the ensuing decades of Baloch nationalism were marked by "assimilation and political pragmatism."98 The partition of 1947 can be viewed as the birth of modern Baloch nationalism. ${ }^{99}$

93 Bhattacherjee, supra note 91, at 10.

94 See Balochistan war: Pakistan accused over 1,000 dumped bodies, BBC (Dec. 28, 2016), https://www.bbc.com/news/world-asia-38454483 [https://perma.cc/4LUKQQYG] ("[M] ost of the bodies 'are of those activists who have been victims of "enforced disappearances" - people who are picked up by authorities and then just go missing.' His allegations chime with an independent Human Rights Commission of Pakistan (HRCP) report in 2013 that noted 'credible reports of continued serious human rights violations, including [enforced] disappearances of people, arbitrary arrests, torture and extrajudicial killings.",).

95 Id.

96 See Baluchistan Hearings, supra note 56, at 81 (statement of Ali Dayan Hasan) ("[S]ince January 2011, at least 300 people have been abducted and killed and their bodies abandoned - acts widely referred to as 'kill and dump' operations, in which Pakistani security forces engaged in counterinsurgency operations may be responsible.”).

97 AHMED \& KHAN, supra note 55, at 48.

98 Id.

99 See Weaver, supra note 64, at 94 ("Then came the Partition in 1947 ... [t]here was immediate chaos in Balochistan. The nawabs and sardars insisted on their right to independence... the khan, to the annoyance of the British and the bewilderment of Pakistan, declared independence. It lasted only eight months, the Pakistani Army moved in and crushed the insurrection, and the Baloch were transformed... they became 
The Baloch national movement today is not fully united. ${ }^{100}$ There are both political movements and militant groups within the movement. ${ }^{101}$ A cause of more recent division in the movement is the response to the Pakistani government's 2009 reforms for Balochistan, Aghaz-e-Haqooq-e-Balochistan ("Beginning of Rights in Balochistan"). ${ }^{102}$ These reforms delegate more authority to Balochistan's provincial government, require the Pakistani government to obtain provincial consent for major projects, and call for "increasing Baloch employment in the civil service, giving provincial and local government authorities a greater share of resource industry revenues, and compensating communities displaced by violence." 103 These reforms have been appealing to the more moderate Baloch. ${ }^{104}$ Today, there is a continuing division within the Baloch people: those who seek a system in which the Baloch people have greater autonomy within the existing state of Pakistan and those who support outright independence. ${ }^{105}$

\section{B. The Efforts of Peter Tatchell}

The cause of self-determination for Balochistan has been buoyed in the international arena by the advocacy of human rights

nationalists.").

100 Balochistan: A road map for peace \& self-determination, PETER TATCHELL FOUND. (Apr. 8, 2013), http://www.petertatchellfoundation.org/balochistan-a-road-mapfor-peace-self-determination/ [https://perma.cc/LLR5-LZAS].

$101 \mathrm{Id}$.

102 See "We Can Torture, Kill, or Keep You for Years" - Enforced Disappearances by Pakistan Security Forces in Balochistan, Hum. RTS. WATch (July 28, 2011), https://www.hrw.org/report/2011/07/28/we-can-torture-kill-or-keep-you-years/enforceddisappearances-pakistan-security [https://perma.cc/XBG2-235F] ("These reforms notwithstanding, doubts persist within Baloch society about the Pakistan government's intentions. Significant Baloch nationalist parties and leaders have rejected the package, claiming it does not adequately address core grievances or genuinely enable greater provincial autonomy .... However, Baloch nationalists are highly splintered, and it is unclear how much influence Baloch political leaders now exert over militant groups.”).

103 Id. at 12.

104 See Anatol Lieven, Pakistan: A Hard Country 343 (Public Affairs 2011) (describing how reforms were not "nearly enough" for Baloch nationalists, but were appealing to moderate Baloch).

105 See Balochistan: A road map for peace \& self-determination, supra note 100 ("The first major challenge is that the Baloch democratic national movement needs to find a way to become more united .... Right now, we have a great deal of disunity with many different political parties and guerrilla movements, sometimes with competing sectarian agendas and political rivalries."). 
activist Peter Tatchell, ${ }^{106}$ a widely-regarded British human rights advocate, progressive, and member of the Green Party. ${ }^{107}$ Tatchell founded the Peter Tatchell Foundation, which "seeks to promote and protect the human rights of individuals, communities, and nations, in the UK and internationally, in accordance with established national and international human rights law."108 Tatchell has been involved in many successful self-determination movements, including in Zimbabwe, Angola, South Africa, and Timor-Leste. ${ }^{109}$

From 2010 to 2013, Tatchell and a group of Baloch national activists worked together on a draft road map for peace and selfdetermination for Balochistan. ${ }^{110}$ In a February 2013 address before a conference of the Unrepresented Nations \& Peoples Organization, ${ }^{111}$ Tatchell outlined a six-point road map for peace and self-determination, a draft "Baloch Freedom Charter," to serve as a "starting point for a united front for Baloch emancipation."112 These six-points include the following:

1. Ceasefire in Balochistan and a halt to all military operations by all sides;

$106 I d$.

107 See Peter Tatchell, THE GuARDIAN (2018), https://www.theguardian.com/profile/petertatchell [perma.cc/B35E-6ZEC].

108 See About Us, PeTER TATCHELl Found, http://www.petertatchellfoundation.org/about/ [perma.cc/G58L-EGT6].

109 See Balochistan: A road map for peace \& self-determination, supra note 100, at $3-4$.

110 Id. at 2.

111 See About UNPO, UnRePresented Nations \& Peoples Org., https://unpo.org/section/2 [https://perma.cc/VV9X-RZP5] ("UNPO was conceived of in the 1980s by exiled leaders of people living under communist oppression, Linnart Mäll of the Congress of Estonia, Erkin Alptekin of the Uyghur people, and Lodi Gyari of Tibet, along with Michael Van Walt van Praag, the international law advisor of the 14th Dalai Lama. A key goal was to replicate the powerful message of nonviolence in the face of oppression exhibited by the Tibetan people and championed by the 14th Dalai Lama. The UNPO was formally founded in 1991 at the Peace Palace in The Hague, by representatives of movements belonging to Australian Aboriginals, Armenia, Crimean Tatars, Cordillera, East Timor, East Turkestan, Estonia, Georgia, the Greek Minority in Albania, Kurdistan, Latvia, Palau, Tibet, Taiwan, Tatarstan and West Papua. Since then, UNPO's membership has also grown steadily from its original fifteen founders, representing now more than 40 Members worldwide, with many former members have achieved their movement's goals and found a formal seat for their people at the national or international level.").

112 See Balochistan: A road map for peace \& self-determination, supra note 100, at 3. 
2. Release of all political prisoners and accounting for all disappeared persons;

3. Allowing the news media, aid agencies, and human rights organizations access to Balochistan;

4. Allowing displaced refugees to return to Balochistan, their properties restored, and compensation received for all losses sustained by the conflict;

5. The ending of the "population transfer" of non-Baloch settlers into Balochistan; and

6. Allowing a UN-supervised referendum on the question of Baloch self-determination to occur. ${ }^{113}$

In his remarks, Tatchell noted that the movement for selfdetermination for Balochistan faces three major challenges. First, Tatchell made a call for unity within the Baloch national movement to create a united national front. ${ }^{114}$ Tatchell also observed that the Baloch movement had very little participation by women and that the success of the movement requires the empowerment of women. ${ }^{115}$ Finally, it was also an obstacle to self-determination that no comprehensive peace and self-determination plan had been developed. ${ }^{116}$ The Baloch Freedom Charter was intended to be a starting point to unite all the Baloch political parties around commonly agreed key principles. ${ }^{117}$

Four years later, in May 2017, Tatchell spoke on Balochistan again before the European Parliament in Brussels, Belgium at a conference hosted by the Unrepresented Nations and Peoples Organization. ${ }^{118}$ In addition to reemphasizing the six key points of the Balochistan Freedom Charter announced in 2013, Tatchell added the following six principles, which could serve as fundamental principles of an independent Balochistan:

1. Social justice, equality, and human rights for all people in Balochistan;

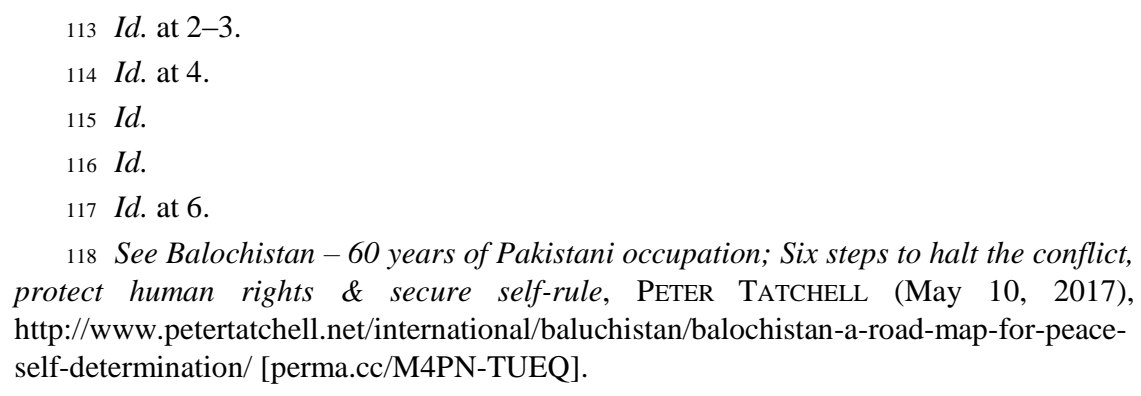


2. Land reform;

3. Redistribution of wealth in Balochistan;

4. A secular state;

5. Democratic freedoms, free multi-party elections, the freedom of speech and press, and the protection of the right to protest; and

6. The establishment of a UN Commission of Inquiry to investigate cases of disappeared persons and victims of torture, extrajudicial killings, and cases of detention without trial. In addition, the establishment of a UN Special Tribunal for Balochistan to investigate potential crimes against humanity, as well as war crimes. ${ }^{119}$

Tatchell has continued to vigorously advocate for Baloch selfdetermination. In November 2017, he was a strong supporter of the World Baloch Organization's effort to place messages on buses in London, such as "Free Balochistan," "Save the Baloch People," and "Stop Enforced Disappearances," to raise awareness of Balochistan. ${ }^{120}$

\section{The United States Congress and H. Con. Res. 104}

No member of Congress has appeared to have advocated more for Balochistan's self-determination than Republican Congressman Dana Rohrabacher of California. Balochistan garnered increased congressional attention in early 2012 with a hearing called by Congressman Rohrabacher before the Oversight and Investigations Subcommittee of the United States House of Representatives Foreign Affairs Committee. ${ }^{121}$ In his opening statement, Congressman Rohrabacher alleged that the Pakistani government had, to that point, "refused to concede any legitimacy to Baluch nationalism or to engage the Baluch leadership in serious negotiations" and that the Pakistani government's response to Baluch nationalism had "been based on brute force, including extrajudicial killings." ${ }^{22}$ The Subcommittee received testimony

119 Id.

120 See Press Trust of India, 'Free Balochistan' Ads Appear on London Buses, NDTV (Nov. 15, 2017), https://www.ndtv.com/world-news/free-balochistan-ads-appear-onlondon-buses-1775479 [perma.cc/49PR-54AK].

121 See Baluchistan Hearings, supra note 56, at 1 (opening statement of United States Representative Dana Rohrabacher of California).

122 Id. at 2. 
from several witnesses, three of whom testified to the numerous human rights abuses occurring in Balochistan. ${ }^{123}$

Several days following the February 8, 2012 congressional hearing on Balochistan, Congressman Rohrabacher introduced $\mathrm{H}$. Con. Res. 104 on February 17, 2012 in the United States House of Representatives, which would express the belief of Congress that Balochistan has the right to self-determination. ${ }^{124}$ The resolution referred to a "plunder of [Balochistan's] vast natural wealth" and noted that "it is the policy of the United States to oppose aggression and the violation of human rights inherent in the subjugation of national groups as currently being shown in Iran and Pakistan against the aspirations of the Baluch people." 125 Finally, the resolution concluded that the people of Balochistan "have the right to self-determination and to their own sovereign country and they should be afforded the opportunity to choose their own status among the community of nations, and to live in peace and harmony, without external coercion." 126 The legislation was co-sponsored by two of the most conservative members of the United States House of Representatives, Congressman Louie Gohmert of Texas ${ }^{127}$ and Congressman Steve King of Iowa. ${ }^{128}$

While the legislation was introduced in the U.S. House of Representatives, and referred to the Subcommittee on Middle East and South Asia of the U.S. House of Representatives Foreign Affairs Committee, it never made it out of the Subcommittee. ${ }^{129}$ No

123 See Baluchistan Hearings, supra note 56, at III (referencing statements by Dr. Hossein Bor, Professor Christine Fair, Ali Dayan Hasan, and T. Kumar).

124 See H.R. Con. Res. 104, 112th Cong. (2012).

$125 I d$.

$126 I d$.

127 See Jay Root, Courting Controversy Works for Gohmert, N.Y. TIMES (Aug. 25, 2012), https://www.nytimes.com/2012/08/26/us/louie-gohmert-texas-republicannotorious-yet-popular.html [https://perma.cc/S27K-UGMD] (describing Gohmert's conservative views on the Constitution, rulings as a judge, and controversies as a Congressman that have garnered praise from very conservative constituents).

128 See Dave Price, Why Steve King Keeps Winning, Politico (Mar. 16, 2017), https://www.politico.com/magazine/story/2017/03/why-steve-king-keeps-winning214913 [https://perma.cc/VMC5-J7B6].

129 See See H.R. Con. Res. 104, 112th Cong. (2012). (describing the historical oppression of Baluchistan and reaffirming their right to self-determination); see also H.Con.Res.104 - Expressing the Sense of Congress That The People of Baluchistan, Currently Divided Between Pakistan, Iran, and Afghanistan, Have The Right To SelfDetermination And To Their Own Sovereign Country, Congress.gOV (2012), 
companion legislation was ever introduced in the Senate, and in subsequent Congresses (113th Congress, 114th Congress, and 115th Congress), the measure has not been reintroduced.

Several members of the United States House of Representatives have expressed support for Balochistan's self-determination in speeches on the floor of the U.S. House of Representatives in recent Congresses. Congressman Rohrabacher has expressed support in remarks on September 21, 2012, ${ }^{130}$ and Congressman Gohmert expressed support in remarks on February 27, 2012 131 and January 29, 2014. ${ }^{132}$ During the February 8, 2012 congressional hearing, Republican Congressman Ted Poe of Texas also mentioned his support for self-determination. ${ }^{133}$

The conservative members of Congress who have supported Balochistan's self-determination expressed a number of reasons. While human rights in Balochistan has been cited by Congressman Rohrabacher, ${ }^{134}$ as well as Congressman Gohmert, ${ }^{135}$ geopolitical concerns in the region have also been cited to support an independent Balochistan. Congressman Gohmert noted reports that supplies to the Taliban in Afghanistan were being transported through Balochistan from Pakistan. ${ }^{136}$ Congressman Gohmert also noted that an independent Balochistan may help cut off supplies to

https://www.congress.gov/bill/112th-congress/house-concurrent-resolution/104/text [https://perma.cc/JS3V-LQAR] (documenting the status and life of the bill).

130158 ConG. REC. E1628 (daily ed. Sept. 21, 2012) (statement of Rep. Rohrabacher).

131 See 158 Cong. REC. H964 (daily ed. Feb. 27, 2012) (statement of Rep. Gohmert) ("[P] erhaps it is time to recognize an independent Baluchistan, where we'd have a friend who would not keep supplying the enemy of America ... empower the enemy of our enemy, the Northern Alliance and the Baluch people. Let them take care of their own area.").

132160 CONG. REC. H1506 (daily ed. Jan. 29, 2014) (statement of Rep. Gohmert).

133 See Baluchistan Hearings, supra note 56, at 93 (referencing the remarks of United States Representative Ted Poe of Texas).

134 Id. at 1 (opening statement of United States Representative Dana Rohrabacher of California).

135 See id. at 93 (referencing the remarks of United States Representative Louie Gohmert of Texas) ("It is greatly disturbing to hear that weapons that we have provided to Pakistan have been utilized to create human rights' violations. That is particularly disturbing. That is not what this Nation is about.").

136 See 160 Cong. ReC. H1506 (daily ed. Jan. 29, 2014) (statement of Rep. Gohmert) ("[M] ost of the supplies to the Taliban are coming from Pakistan through the southern Baloch area of Pakistan, and maybe if Balochistan was independent of Pakistan, that would cut off the supply to the terrorist Taliban."). 
the Taliban. ${ }^{137}$ Eddie Walsh, a senior foreign correspondent, has observed that Congressmen Rohrabacher and Gohmert generally support an alternative foreign policy approach in southwest Asia by advocating for the interests of the National Front of Afghanistan in Afghanistan $^{138}$ and the Baloch in Balochistan over the sovereign interests of Afghanistan and Pakistan. ${ }^{139}$ In essence, the argument is that an independent Balochistan would serve United States foreign policy interests in the ongoing conflict with the Taliban that has lasted approximately seventeen years. ${ }^{140}$ Walsh has also noted that the congressional effort for self-determination for Balochistan is linked with sentiment critical of Pakistan, and that another strong rationale for support could be that an independent Balochistan would place a check on China's influence with the Gwadar port and Iran's influence in the Strait of Hormuz. ${ }^{141}$

\section{U.S. Foreign Policy and Balochistan}

The United States Department of State has expressed concerns over human rights abuses in Balochistan. In its most recent report

137 Id.

138 See Eddie Walsh, Should the US support an independent Balochistan?, AL

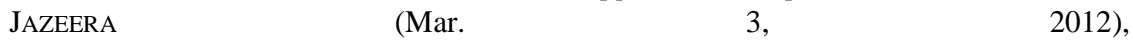
https://www.aljazeera.com/indepth/opinion/2012/02/201222112203196390.html [https://perma.cc/ZD8V-FZUF] ("This alternative policy centers on backing remnants of the Northern Alliance and Baloch insurgents"); TOM LANSFORD, AFGHANISTAN AT WAR: From The 18Th Century Durrani Dynasty To The 21st Century 310-11 (Tom Lansford ed., ABC-CLIO, LLC, 2017) (giving a brief overview and history of the National Front of Afghanistan).

139 See Walsh, supra note 138 ("Rohrabacher . . . and Representative Steve King . . introduce[ed] a new bill in Congress stating that the Baloch nation has a historic right to self-determination ... advancing a revolutionary alternative policy approach that called for supporting the minority interests of the Northern Alliance and Baloch against the sovereign interests of Afghanistan, Iran, and Pakistan.”).

140 See Ryan Browne, 17 years in, Afghan war at a 'stalemate, ' CNN (Nov. 27, 2018, 7:11 PM), https://www.cnn.com/2018/11/27/politics/us-afghan-war-stalemate/index.html [https://perma.cc/PKR3-LTLB] ("It's not entirely static but for the most part it's a stalemate.").

141 See Walsh, supra note 138 ("When one discusses Balochistan, you are discussing a way to contain China ... This is of strategic interest to the United States because Chinese ships would have a direct route to China and no longer have to transit past the Indian and American navies .... Iran is an empire and they are using Baloch lands to try to become the dominant regional player. The Iranians are using the Strait of Hormuz as a choke-point for a huge percentage of the world's oil. They also are building a pipeline to Pakistan which violates UN sanctions. Such growing Iran-Pakistan cooperation is a major concern."). 
on human rights in Pakistan in 2017, the Department of State noted that there were numerous reports of arbitrary or unlawful killings and abductions in Balochistan. ${ }^{142}$ This same report also stated that journalists, teachers, students, and human rights activists were targeted in Balochistan. ${ }^{143}$

Although there are numerous human rights abuses in Balochistan, the United States government has remained adamant in its opposition to self-determination for Balochistan. The topic of self-determination for Balochistan was addressed specifically in a September 2016 news briefing at the United States Department of State. ${ }^{144}$ In that briefing, State Department spokesman Admiral John Kirby expressly mentioned that the policy of the United States was to support the territorial integrity of Pakistan and oppose independence for Balochistan. ${ }^{145}$ While this statement was made during the Obama Administration, as of this date, the Trump Administration has not expressed any major change in United States foreign policy with regard to self-determination for Balochistan.

\section{E. International Law, Self-Determination and Balochistan}

With the advocacy of Baloch nationalists, including Peter Tatchell, and several members of Congress, the question of selfdetermination for Balochistan remains a prominent issue in international law. In the wake of the Quebec Case and the Kosovo Advisory Opinion, there are several robust arguments to be made for Baloch self-determination given the history of Balochistan, the current human rights situation in the region, and Pakistan's relationship with Balochistan.

142 See U.S. Dep't of State, Bureau of Democracy, H.R. and Lab., supra note 87, at 2, 4, 18 (referencing numerous reports of authorities committing arbitrary or unlawful killings, disappearances, and abductions of human rights advocates by security forces in connection with the conflict in Balochistan).

143 Id. at 4, 5, 18.

144 See News Desk, Islamabad slams Delhi's bid to raise Balochistan issue at UN, THE EXPRESS TRIB. (Sept. 16, 2016), https://tribune.com.pk/story/1182346/islamabadslams-delhis-bid-raise-balochistan-issue/ [https://perma.cc/3AYL-M42Y] ("When asked whether the US tolerates those working from US soil to break the province off from Pakistan, [State Department Spokesperson] Kirby reiterated his statement that Washington does not support any such movement.").

$145 I d$. 


\section{Self-Determination as a Remedial Right Due to Human Rights Violations}

Under the remedial right theory of secession, ${ }^{146}$ there is purportedly a right to secede in cases where other rights have been violated. ${ }^{147}$ This right would arise in certain situations, including where there are "large-scale and constant violations of basic human rights." 148 Several academic commentators have remarked "that the human rights situation in Balochistan is fairly grave [and] cannot be denied by any impartial observer." 149 While the remedial right theory provides a strong moral justification for the right to selfdetermination, ${ }^{150}$ it should be noted that the theory has a major shortcoming in that it has not been fully established as a principle in international law.

However, with the widespread targeting of human rights

146 See, e.g., Simon, supra note 8, at 143 (2011) ("The Remedial Model goes beyond proposing merely a liberty right to secede, which focuses on whether the right should be permitted. Instead, the Remedial Model invokes a stronger, moral right to secede, which, unlike a liberty right, places obligations on others not to interfere with the secession process."); see also id. at 145 ("Secession rights are remedial rights invoked by a group under limited conditions to rectify harms; they are not rights that apply to all citizens in general."). The origin of the remedial theory is from philosopher Allen Buchanan. See Allen Buchanan, Self-Determination, Secession, and the Rule of Law, THE MoRALITY OF NATIONALISM 301-323 (Robert McKim \& Jeff McMahan, eds., 1997) ("The approach I began to develop there construes the right to secede as a remedial right . . . as a remedy of last resort for serious injustices."). For further discussion of the remedial theory, see also Steven R. Fisher, Towards "Never Again": Searching for a Right to Remedial Secession Under Extant International Law, 22 Buff. HuM. RTS. L. REV. 261, 266 (2015-2016) ("Secession for this purpose, correcting human rights violations, has been termed remedial secession ... and will be the specific focus of this Article."); Lea Brilmayer, Secession and the Two Types of Territorial Claims, 21 ILSA J. INT'L \& COMP. L. 325, 326-27 (2015) (providing a brief definition of the remedial theory and how it differs from a competing theory); Meller, supra note 16, at 846-47 (2012) (illustrating remedial succession and some issues it has faced as a theory).

147 See Karmanye Thadani, Mohammad Irfan Sohail \& Devender Dhyani, The Right to Self-Determination of Pakistan's Baloch: Can Balochistan Go the Kosovo Way? 40 (Lambert Academic Publishing 2013) ("Remedial rights theories analogize the right to secede to the right to revolution, understanding it as a right that a group comes to have only as a result of violations of other rights ... The right to unilateral secession thus derivate upon the violation of other, more basic rights.").

$148 I d$. at 41.

149 Id. at 47.

150 See Simon, supra note 8, at 143 ("The Remedial Model goes beyond proposing merely a liberty right to secede . . . the Remedial Model invokes a stronger, moral right to secede."). 
activists and political activists in Balochistan, and extensive documented instances of extrajudicial killings, disappearances, and torture, ${ }^{151}$ the moral argument for self-determination for Balochistan to promote and uphold human rights is a salient one. Perhaps Balochistan's strongest argument for self-determination is the positive impact that independence could have on the protection of human rights. It is significant that the United States Department of State, which has followed a policy of opposing self-determination for Balochistan, has acknowledged that there is a "culture of impunity" among perpetrators of human rights abuses in Balochistan and that a "lack of accountability" exists in Balochistan. ${ }^{152}$ Furthermore, and perhaps most significantly, the same 2017 report on human rights practices in Pakistan notes that a "culture of lawlessness" exists in Balochistan. ${ }^{153}$ As a remedial measure, self-determination arguably has a very strong rationale in situations not only where large scale and widespread human rights violations occur, but where they are coupled by a lack of accountability as well. Arguably, Balochistan falls within this category, and an independent Balochistan with governance by the Balochi people may reduce the severity of the human rights violations in the region that have allegedly occurred by both the Pakistani security forces, as well as militant Baloch nationalists.

Within the past several years, there has been a disturbing development in that the Islamic State ("ISIS") ${ }^{154}$ has appeared to increase its attacks in Balochistan. ${ }^{155}$ In July 2018, Siraj Raisani, a prominent Pakistani politician, was assassinated in a suicide bombing in Balochistan prior to the 2018 elections in Pakistan. ${ }^{156}$

151 See generally, Baluchistan Hearings, supra note 56.

152 See U.S. Dep't of State, Bureau of Democracy, H.R. and Lab., supra note 87, at 1 ("There was a lack of government accountability, and abuses often went unpunished, fostering a culture of impunity among the perpetrators, whether official or unofficial.").

$153 I d$. at 2.

154 See generally Graeme Wood, What ISIS Really Wants, The AtLantic (Mar. 2015), https://www.theatlantic.com/magazine/archive/2015/03/what-isis-really-wants/384980/ [https://perma.cc/8HXU-T5UT].

155 See Akbar, supra note 54.

156 Memphis Barker, Nawaz Sharif arrested on arrival in Pakistan as 132 people die in bombing, THE GUARDIAN (July 13, 2018), https://www.theguardian.com/world/2018/jul/13/suicide-bomb-attack-kills-85-andwounds-100-at-mastung-pakistan-election-rally [https://perma.cc/9FXW-Q833]. 
ISIS claimed responsibility for the attack. ${ }^{157}$ Malik Siraj Akbar, a journalist, contends that Pakistan's strategy in recent years of utilizing more extreme Islamist groups to battle Baloch separatists has led to a situation where ISIS militants have emerged to destabilize the region and Pakistan. ${ }^{158}$ Akbar further opined that the Pakistani military appears to "be deluded that they can use and control these groups." 159 An independent Balochistan, strengthened by independence and external support, can stand as a bulwark against ISIS to better protect the human rights of the Baloch people.

\section{Self-Determination as a "Last Resort" Due to Lack of Meaningful Access to Government}

As indicated in the Quebec Case, a right to secession exists in cases where a people are denied their right to internal selfdetermination and "meaningful access to government." 160 As the Supreme Court of Canada noted in the Quebec Case, the sharing of a common language and culture are two significant characteristics which are common among a "people" for purposes of international law. ${ }^{161}$ With the case of Balochistan, as discussed above, there is a unique Balochi language and the Baloch people have a longstanding unique cultural history. Thus, the Baloch people arguably qualify as a "people" for purposes of international law.

A strong argument for Baloch self-determination is that the population of Balochistan is arbitrarily and capriciously being denied a fair distribution of the province's resources, particularly with the CPEC alliance. As Congressman Ted Poe remarked in 2012, "[t]he Baluch people have the resources to take care of themselves, but the government of Pakistan takes the resources and either puts tight constraints on the profit that goes back to the Baluchs or gives the profit away to its friends." 162 With regard to gas, Congressman Poe stated the Balochistan province only received $\$ 0.29$ per thousand cubic feet for gas, as compared to the Punjab province, which received $\$ 2.35$ per thousand cubic feet, and

\footnotetext{
157 Id.

158 See Akbar, supra note 54.

159 Id.

160 Reference re Secession of Quebec, 37 I.L.M. at 1342, 1373.

161 Id. at 1371.

162158 Cong. ReC. E649 (daily ed. Apr. 25, 2012) (statement of Rep. Poe).
} 
the Sindh province, which received $\$ 1.65$ per thousand cubic feet. ${ }^{163}$ The CPEC is also a major concern to the Baloch, as Pakistan and China are set to receive a major financial windfall from the corridor. ${ }^{164}$ The province of Balochistan is set only to receive 0.5 percent of the profits from CPEC. 165 Of revenues which will arise from the Gwadar port, 91 percent are contracted to go to the Chinese government, 9 percent to the Pakistani government, and nothing to the Balochistan provincial government. ${ }^{166}$

The "meaningful access to government" part of the Quebec Case's test for internal self-determination requires an inquiry to determine whether a people can obtain representation in governmental institutions. ${ }^{167}$ Pakistan has two parliamentary bodies, the National Assembly of Pakistan and the Senate. ${ }^{168}$ The National Assembly is the more powerful of the two houses. ${ }^{169}$ Balochistan has only seventeen seats out of 342 seats in the National Assembly, ${ }^{170}$ which provides Baloch interests a minimal voice in Pakistan's parliamentary process. ${ }^{171}$

In the Quebec Case, the Supreme Court of Canada noted that it could not be plausibly denied that the people of Quebec had access to government. ${ }^{172}$ The Supreme Court of Canada stated:

Quebecers occupy prominent positions within the government of

$163 I d$.

164 Akbar Shahid Ahmed, China and Pakistan Plan to Get Rich Together. The Price? Human Rights., HufFington Post (Aug. 5, 2018, 4:15 PM), https://www.huffingtonpost.com/entry/china-pakistan-balochistan-gwadar-plan-humanrights_us_5b560d39e4b0fd5c73c7c122 [https://perma.cc/T8F2-RMA8].

165 Shazar Shafqat, CPEC and the Baloch Insurgency, ThE DiPLOMAT (Feb. 8, 2017), https://thediplomat.com/2017/02/cpec-and-the-baloch-insurgency/ [https://perma.cc/N9UV-NQTQ].

166 Adnan Aamir, Pakistan's CPEC Projects Leaving Balochistan Behind, ASIA TIMES (Apr. 25, 2018), https://www.asiatimes.com/2018/04/opinion/balochistan-is-beingleft-behind-by-cpec/ [https://perma.cc/S9RQ-N8PE].

167 See Reference re Secession of Quebec, 37 I.L.M. at 1342, 1373.

168 Baluchistan Hearings, supra note 56, at 20 (noting statement of Assistant Professor Christine Fair, PhD., Georgetown University).

169 Id.

170 Id ; see Composition, NAT'L ASSEMBLY OF PAK. http://www.na.gov.pk/en/composition.php [https://perma.cc/VWV2-QSAD].

171 But see Government has bypassed all roads and bypass plans in Balochistan,

ASIANET PAK. (Sept. 13, 2019), https://asianetpakistan.com/general/402684/governmenthas-bypassed-all-roads-and-bypass-plans-in-balochistan/ [https://perma.cc/7SEX-2FLF].

172 Reference re Secession of Quebec, 37 I.L.M. at 1342, 1373. 
Canada. Residents of the province freely make political choices and pursue economic, social and cultural development within Quebec, across Canada, and throughout the world. The population of Quebec is equitably represented in legislative, executive, and judicial institutions. In short, to reflect the phraseology of the international documents that address the right to selfdetermination of peoples, Canada is a "sovereign and independent state conducting itself in compliance with the principle of equal rights and self-determination of peoples and thus possessed of a government representing the whole people belonging to the territory without distinction." 173

In contrast to the Quebec Case, the Baloch people have very limited representation in Pakistan's government and are receiving limited government benefits. ${ }^{174}$ In fact, Balochistan is arguably "denied the use of its own resources." 175

The essential exclusion of Balochistan from any proceeds of the Gwadar port, miniscule financial interest in the CPEC alliance, and severely limited representation in Pakistan's parliament creates a compelling argument that the current situation in Balochistan meets the Quebec Case's definition of a people being denied internal means of self-determination due to a lack of meaningful access to government.

\section{F. An Opportunity for Conservative and Progressive Bipartisan Support for Self-Determination for Balochistan?}

The advocacy for Balochistan's self-determination of progressive human rights campaigner Peter Tatchell and some of the most conservative members of the United States Congress opens up the possibility of an opportunity for a bipartisan coalition to develop. Walsh has remarked that the issue of human rights in Balochistan may be a "powerful advocacy tool" to support the movement for self-determination. ${ }^{176}$ Support for increased protections for human rights in Balochistan may perhaps be the most compelling argument for self-determination, and it likely will

173 Id.

174 Baluchistan Hearings, supra note 56, at 20 (statement of Assistant Professor Christine Fair, PhD., Georgetown University).

175 Id. at 17.

176 Walsh, supra note 138. 
have broad-based appeal to both conservatives and progressives.

However, Balochistan's strongest ally in Congress, Dana Rohrabacher, was defeated in the 2018 midterm congressional elections. ${ }^{177}$ Congressman Ted Poe, who also took interest in Balochistan, retired. ${ }^{178}$ The absence of Rohrabacher's presence in the 116th Congress will be difficult for the visibility of the movement to support self-determination in Balochistan. Yet, two outspoken advocates for self-determination, Republicans Louie Gohmert ${ }^{179}$ and Steve King, ${ }^{180}$ are returning to the 116 th Congress. Democratic Congressman Brian Higgins, who has not specifically endorsed self-determination for Balochistan but has shown some interest in the movement, is returning to the 116th Congress. ${ }^{181}$ In February 2013, Congressman Higgins attended a forum sponsored by the Unrepresented Nations and Peoples Organization on the future of Balochistan at the Royal Society in London. ${ }^{182}$ However,

177 Devan Cole, California Democrat Harley Rouda defeats longtime Rep. Dana

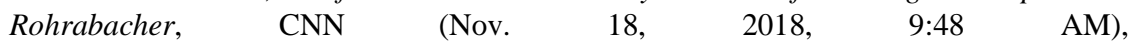
https://www.cnn.com/2018/11/18/politics/harely-rouda-dana-rohrabacher-house-

election/index.html [https://perma.cc/G4C9-9DH3]; see Balochistan: US Congressman Rohrabacher Calls for Pakistani Officials To Be Tried for 'War Crimes, ' UNREPRESENTED NATIONS \& PEOPLES ORG. (Feb. 27, 2013), https://unpo.org/article/15565?id=15565 [https://perma.cc/9X9R-57E3].

178 Eli Watkins, Texas Republican Rep. Ted Poe announces retirement, CNN (Nov. 7, 2017, 7:36 PM), https://www.cnn.com/2017/11/07/politics/ted-poeretirement/index.html [https://perma.cc/SBT5-69NY]; see Balochistan: US Congress Hears of Persecution, UnRePresented NATIONS \& PeOPles ORg. (Apr. 27, 2012), https://unpo.org/article/14209 [https://perma.cc/BH26-MFKT]; see Baluchistan Hearings, supra note 56 (remarks of United States Representative Ted Poe of Texas).

179 Patrick Cunningham, Gohmert easily re-elected to 8th term in U.S. House of representatives, E. TEX. MATTERS (Nov. 6, 2018, 8:12 PM), https://www.easttexasmatters.com/news/top-stories/gohmert-easily-re-elected-to-8thterm-in-us-house-of-represenatives/1577084867 [https://perma.cc/74ZP-DSEE]; see Jay Root, Courting Controversy Works for Gohmert, N.Y. TiMES (Aug. 25, 2012), https://www.nytimes.com/2012/08/26/us/louie-gohmert-texas-republican-notorious-yetpopular.html [https://perma.cc/S27K-UGMD].

180 Laura Curtis, Steve King Wins Re-Election in Closely Watched Iowa House Race, BLOOMBERG (Nov. 7, 2018, 12:07 AM), https://www.bloomberg.com/news/articles/201811-07/steve-king-wins-re-election-in-closely-watched-iowa-house-race [https://perma.cc/GR2P-PSVA]; see Price, supra note 128.

181 Mike Lillis, Pelosi momentum builds as detractor backs her, THE HILl (Nov. 21, 2018, 11:38 AM), https://thehill.com/homenews/house/417831-pelosi-momentum-buildsas-detractor-backs-her [https://perma.cc/B2UG-Q3MU].

182 Balochistan: US Congressman Rohrabacher Calls for Pakistani Officials To Be Tried for 'War Crimes,' supra note 177. 
he was not a co-sponsor of H. Con. Res. 104. ${ }^{183}$

As the 116th Congress is underway, the issue of selfdetermination for Balochistan is one that both conservatives and progressives can examine together to work toward the promotion of human rights. Despite the partisanship in Washington, vocal advocacy for human rights crosses party lines. The 2012 congressional hearing on Balochistan conveyed that the Republican and Democratic members of Congress who spoke during the hearing mentioned human rights concerns. ${ }^{184}$ Although outside of the United States, the advocacy work of the Green Party's Peter Tatchell shows that progressives, as well as conservatives, can both be vocal in support of Balochistan. ${ }^{185}$ In fact, Tatchell, an ardent progressive, and Congressman Rohrabacher, an ardent conservative, spoke at the same forum on Balochistan sponsored by the Unrepresented Nations and Peoples Organization in 2013. ${ }^{186}$ The common ground in promoting human rights and the dignity and worth of every individual provides an opportunity for both Republicans and Democrats, conservatives as well as liberals, to work together on Balochistan and to at least address the issue of improving human rights in the region and the various arguments concerning self-determination in policy debates.

In recent months, Balochistan has continued to receive international media attention. Protests in London have drawn attention to the alleged abduction of women and children by the Pakistani military ${ }^{187}$ and protests in Quetta have been held against enforced disappearances. ${ }^{188}$ The issue of self-determination is not

183 H.R. Con. Res. 104, 112th Cong. (2012).

184 See generally Baluchistan Hearings, supra note 56.

185 Pak Left Red-Faced At UN As Baloch Activists Expose Islamabad's Hypocrisy, NDTV (Sept. 11, 2019), https://www.ndtv.com/world-news/pakistan-left-red-faced-at-unas-baloch-activists-expose-islamabads-hypocrisy-2099354 [https://perma.cc/8XVRHTFB].

186 U.S. Congressman Dana Rohrabacher Demands Referendum in Balochistan on the Question of Independence, UNREPRESENTED NATIONS \& PEOPLES ORG. (Feb. 11, 2013), https://unpo.org/article/15484 [https://perma.cc/5NKT-YCUS].

187 OpIndia Staff, Watch: Balochistan activists hold protests in London against abduction of women and children by Pakistan Army, OpInDIA (Oct. 1, 2019), https://www.opindia.com/2019/10/watch-balochistan-activists-hold-protests-in-londonagainst-abduction-of-women-and-children-by-pakistan-army/ [https://perma.cc/K387DHTP] (last visited Oct. 26, 2019).

188 ANI, Baloch women, children hold protest against enforced disappearances, ANI (Oct. 23, 2019), https://www.aninews.in/news/world/asia/baloch-women-children-hold- 
completely lost in recent policy discussions. ${ }^{189}$

\section{Conclusion}

With the 2020 elections approaching, the political atmosphere within the United States remains highly polarized. ${ }^{190}$ In the realm of foreign policy, immigration and migration from Mexico and other countries garner much attention from policymakers. ${ }^{191}$ Unfortunately, the situation in Balochistan generally does not receive as much attention, despite the presence of several robust arguments under international legal principles to support selfdetermination for Balochistan.

With the 2020 presidential campaign underway, bipartisanship in the United States Congress may be difficult to generate. However, U.S. policy with regards to Balochistan is an area where both conservatives and progressives can align together and place politics aside to promote human rights and the dignity and worth of every human being. By engaging in policy debates concerning the possibility of self-determination for Balochistan, conservatives and progressives can work together to promote human rights in Balochistan, the surrounding region, and throughout the world.

189 Saket Suman, Watching 'Bard of Blood' \& 'Family Man'? Here's a Background Of The Problem in Balochistan, INDIA TIMES (Sept. 30, 2019), https://www.indiatimes.com/news/world/watching-bard-of-blood-family-man-here-s-abackground-of-the-problem-in-balochistan-376744.html [https://perma.cc/VG3N-L5KN] (last accessed Oct. 26, 2019).

190 Jason Puhr, Michigan State University study shows polarized politics at worst levels in U.S. history, WWMT (Nov. 6, 2018), https://wwmt.com/news/local/study-showspolarized-politics-at-its-worst-in-us-history [https://perma.cc/C7MX-Z6HF].

191 See, e.g., Kevin Breuninger \& Tucker Higgins, Trump Unveils hard-line immigration policy that limits asylum, CNBC (Nov. 9, 2018, 9:56 AM), https://www.cnbc.com/2018/11/08/trump-unveils-hard-line-immigration-policy-thatlimits-asylum.html [https://perma.cc/KXJ8-ABXJ]. 
